\title{
Teaching English as a Foreign Language to 4th Grade Students by Using Technology
}

\author{
Yunus Yildiz ${ }^{1}$ \\ ${ }^{1}$ Department of Language Teaching, Tishk International University, Erbil, Iraq \\ Email: yunus.yildiz@tiu.edu.iq
}

DOI: $10.53103 /$ cjlls.v1i2.16

\begin{abstract}
Language is one of the most important components that affect international communication activities. Technology plays a crucial role for teachers to facilitate language learning for their students. Each language class frequently uses various forms of technology. Technology has been used to help and improve language learning process. With the help of technology, teachers adapt classroom activities by enhancing the language learning process. The study was conducted on 4th grade students studying at different schools affiliated to the Ministry of National Education in the 2020-2021 academic year. The study was carried out with a total of 10 students. In this study, qualitative research design was used based on the method used concerning participant observations and in-depth interviews. Motivation scale, presentations for English course and online education and computer-aided teaching software were used to collect data in the study. The results have examined how technology influences foreign language learning and how it aids to students in reading while learning English.
\end{abstract}

Keywords: Technology, Foreign Language Learning, Online Education, Computer-Aided Teaching Software

\section{Introduction}

Language is one of the most important components that affect international communication activities. Students generally benefit from various parts of English language skills such as listening, speaking, reading, and writing for their proficiency and communication. Computers are known as a crucial instrument in foreign language classes where educator's teachers feel themselves free while applying the curriculum.

Technology plays a crucial role for teachers to facilitate language learning for their students. Each language class frequently uses various forms of technology. Technology has been used to help and improve language learning process. With the help of technology, teachers adapt classroom activities by enhancing the language learning process. The use of technology has recently become a significant part of the learning process in and out of the class. Being an indispensable part of the learning experience, technology has been a pivotal 
issue for language teachers, from the beginning of preparing learning experiences through to teaching and learning process. Technology has always been an important part of teaching and learning environment. It is an integral part of the teachers' profession through which they can use it to facilitate learners' learning. With technology being part of our everyday lives, it is time to rethink the idea of integrating technology into the curriculum and aim to embed technology into teaching to support the learning process.

In recent years, there has been much research on diverse aspects of teaching and learning a second language. "One of the most important developments that affect teachers and learners in language education programs is educational technology, in particular the use of the computer in the language classroom" (Warschauer, 2000; Chapelle, 2000; Levy, 2000, p.303).

With the advent of internet-based devices, especially in several developing countries, both information technology and English language education have developed rapidly over the past few decades. Thanks to rapidly developing technology, several authentic materials let learners be motivated in the process of foreign language learning. Information technology and communicative competence in English have become central to the move towards globalization. The number of English learners and teachers using computers has increased significantly over the past few decades. One of the areas of most rapid expansion in English language education in Turkey is Computer-Assisted Language Learning (CALL). The range of possibilities in CALL has become wider than ever before, with the technology related to computers and networks developing at a tremendous pace. The use of CALL in English teaching and learning is now very diverse, including the use of multimedia-based CD ROMs, E-mail and the Internet, as well as more traditional word processing and instructional software. Students are able to monitor their learning process by using technology. Technology helps learners access to a great deal of information that their teachers cannot provide. The use of technologies has the great potential to change the current language teaching methods. Methods of foreign language teaching have dramatically altered in recent years on the basis of learners' needs or interests due to technology.

The use of technology has changed the methods from teacher-centered to learnercentered ones. It assists them in gathering information and interacting with resources such as videos. There are two different views about how to integrate technology into the class: First, in the cognitive approach, learners get the opportunity to increase their exposure to language meaningfully and make their own knowledge. Second, in the social approach, learners must be given opportunities for authentic social interactions to practice real life skills. This objective can be obtained through the collaboration of learners in real activities.

As for computer-based communication, it is a fairly useful feature for language learning. Computer-assisted discussion features more equal participation than face to-face discussion. "Technology helps learners and teachers in studying the course materials owing 
to its fast access" (Rodinadze \& Zarbazoia, 2012, p.123).

One of the reasons that administrators buy CALL software is with the hope of providing an integrated teaching solution; something that will

a) offer a language learning curriculum

b) provide realistic, native-speaker models of the language in a variety of media

c) carry out a needs assessment

d) determine the best next step for the learner and provide practice with that skill area

e) be eligible and do not need anything else

f) record what the student has done, along with an evaluation

Similarly, technology has an important role in promoting activities for learners and has a significant effect on teachers' teaching methods. If teachers do not use technologies in their teaching they will never be able to keep up with these technologies. For that reason, "it is very important for teachers to have a full knowledge of these technologies in teaching language skills" (Solanki \& Shyamlee, 2012, p.12).

The benefits of adding a technology to language instruction vary in diverse ways, and include the following:

a) individualization in a large class

b) multimodal practice with feedback

c) the fun factor

d) pair and small group work on projects, either collaboratively or competitively

e) variety in the resources available and learning styles used

f) real-life skill-building in computer use

g) exploratory learning with large amounts of language data

Advances in technology have a key role in preparing learners to use what they learn in any subject matter to finding their place in the world labor-force. Technology facilitates learners' learning and serves as a real educational tool that allows learning to occur. Modern technologies like computers are regarded as feasible and sufficient tools for offering learning activities which particularly simulate real and authentic language use, and thus resulting in meaningful learning. Technology tools show an improvement when it comes down to accessibility and motivation. The immediate feedback learners receive is a benefit of using technology. They usually learn vocabulary, spelling, and sentence structure by reading the work of their classmates.

A good education system is the main feature of a strong knowledge society. The aim of the societies that are in a quest and race in order to adapt to the new conditions created by the developing science and technology is to become an information society. Information societies can easily access and use information, and then contribute to its 
production, with the power to analyze and synthesize needs of individuals who are creative, who have the ability to evaluate and communicate, and who have assimilated universal values. For that reason, education systems have to train human power with these characteristics.

When we compare traditional classroom education with technology-aided foreign language education, the individual education process faced by each student rises to a very high level with the help of computers. The main reason for this is that when each student tries to learn via computer, which we can think of as a teacher, the student is alone with his or her teacher until the end of the lesson, and the ratio of problem solving, analyzing, synthesizing and the ratio of questions he or she has to answer will be clearly seen when compared with the ratio in traditional classroom education. In a broader sense, the program in traditional education is usually prepared assuming that all students learn at the same time and at the same speed. "Traditional teaching is uniform; it does not take into account the individual differences of students in terms of interest, experience and ability" (Yildırım, 1988, p. 46). All students are offered the same content and it is thought that all of their students are progressing at the same pace. "Teaching is subject-centered; attaches importance to teaching certain subjects rather than student learning" (Tezcan, 1988, p.12). Traditional education is the most used and best known approach in our education system today. In this period of information age, teachers often resort to traditional classroom teaching. In traditional education, the teaching in the classroom is directed by the lesson plan under the control of the teacher. "Teaching is done in precise and stereotyped timelines" (Alkan, 1979, p.21). Besides, "in traditional education, the student is in a passive learning situation such as listening, looking and taking notes" (Doğan, 1997, p.11). In the learning-teaching process, it is not possible for the student to directly interact with various sources of information. The main source of interaction between content and student is the teacher. The student's inability to directly interact with the sources of information renders the student passive in the learning process. As a matter of fact, there are different reasons for problems with English education. Most English teachers will admit that student motivation is one of the most important factors affecting students' success or failure in language learning. "Students with adequate motivation may be more successful in learning” (Taşpınar, 2004, p.25).

In modern age, education circles are working to benefit from computers in the education and training process. It combines the idea that the understanding will accelerate the change process and has an important role in training the manpower that the information society needs. Information-communication technologies have entered English classes in our country as well as in the world and will continue to do so. "In the developing and changing technology age, the need for technology-supported materials that will make technological products work more and more shows itself' (Cepni et al., 2006, p.66).

With the advent of technological opportunities, research and development studies 
on computer games have gained momentum in recent years. "Computer games, which are the subject of academic conferences, meetings, studies and books, have been shown as appropriate applications aimed at learning" (Gee, 2003, p.88).

In one of the biggest conferences in Europe (Online Educa in Berlin) held in the field of e-learning in 2006, the problems in the use of computer games for learning purposes and the games for learning within the framework of these problems were examined with their pros and cons. New technologies that emerged in the second half of the twentieth century have reached the power to change social and economic conditions all over the world. In many parts of our daily life, we live with these technologies, consciously or not. One of the technological products that has attracted great attention in our country in recent years is computers. The word computer has become a word we hear and use frequently in our daily life. Computer is a tool that many of us have come to know for one reason or another. By taking part in all commercial, industrial and educational activities of the societies, it has increased productivity in every area of use and has an important place in human life. It has ceased to be a foreign concept for many people. "Education is the process of bringing about an intended change in an individual's behavior through his own life" (Taşpınar, 2004, p.25). Computers, which are inevitable to be used in all areas of education, are affected by the rapid changes in science and technology.

To date, the educational activities in our country has been handled depending on common sense rather than a scientific approach. Education and culture have always been linked with the establishment and adoption of ideas rather than the change. However, the era we live in today has an unstable character and is characterized by rapid change. "In this environment, skills based on mechanization gave way to skills based on information technology" (Arslan, 2003, p.35). Today, the change in human's relations with knowledge and society has also changed his characteristics. In the light of rapidly changing and developing technologies, a short time after the emergence of computers, which actually did not have much history, computer games were introduced in addition to the work of computers. "While children spent an average of 4 hours a week at home and in the arcade halls in the mid-1980s, today girls spend 5.5 hours a week in primary and secondary school students, while this time reaches 13 hours a week for boys" (Christakis, Ebel, Rivara, \& Zimmerman, 2004, p.112).

It is crucial to use computer games for children who devote most of the day to games. Using these environments that attract and motivate all of them, whether male or female, is one of the areas that should be concentrated. In this way, the disadvantages of traditional classroom environments can be eliminated and teaching situations can be made interesting.

Educational computer software stands out not only for those who use that software, but also for trainers. Educational computer games have a structure that helps students to develop their skills and contains information patterns specific to the subject area they are 
prepared for. In other words, educational computer games have a feature that makes the student a pleasant time, but also teaches information in the activity or reinforces previous knowledge. "Educational computer games can be employed to achieve the goals included in education and training programs" (Bottino, Ferlino, Ott, \& Travella, 2006, p.14).

In addition to features such as games, races and luck, it also includes many features of problem solving such as unknown result, alternative solutions, problem structuring, and cooperation. "In game-based environments, students create their problems themselves, collect the necessary information for the solution, and solve the problem within the framework of their findings" (Bottino et al., 2006; Ebner \& Holzinger, 2007, p.12). When these aspects of the games are considered together, the opportunities provided in the teaching process enable the learners to have fun and productive lives as well as visualization and therefore the permanence of the learners.

In the field of language teaching, there is a greater need for scientific innovations and technological inventions compared to other sciences in social sciences. "The main reason for this is to produce sounds and images belonging to the speakers of the taught language, and then to use them in language classrooms and laboratories as a course material" (Kartal, 2005, p.26). Learning a foreign language can only be possible by discovering the behavior and life styles of those who speak that language, briefly their culture.

In conrast to the classical learning theory based on the "stimulus-responsereinforcement" principle, the "reinforcement" process for a permanent learning / teaching can only be achieved by rewarding the right responses. This learning theory put forward by Skinner can be summarized as follows: "Stimulant - Student's reaction - Notifying the student of the correct reaction (reward) - The student's repetition of the correct response (reinforcement)" (Kartal, 2005, p.11). It is one of the effective teaching approaches of the behavioral learning school in school education. In fact, classroom teaching carries a number of problems. In classroom teaching, stimulating situations are usually presented to all students at the same time.

It is necessary to focus on different points in order to realize effective learning in the game environment although educational computer games that combine educational learning environment and game concepts are similar to the design process of other educational environments in terms of their structure. In this context, "developed design models for educational computer games are needed" (Akgün et al., 2011, p.11). It has started a new era in which educational computer games, which continue to increase in importance in every field, will provide effective learning processes in language teaching and learning activities can be carried out at an individual pace anytime, anywhere with permanent learning. It is recommended to prepare educational computer software in language teaching by taking design models into consideration and conduct researches to examine its effectiveness. Computers, which have become an indispensable tool of modern 
life, offer great opportunities for English education. It seems inevitable that technology will cause changes in various fields.

Studies of the Ministry of National Education in Turkey in this field also support technology assisted language education. DynEd, which has been implemented in schools, is an interactive education program on the Dynamic Education English Language Education System and is used as an auxiliary lesson tool in English lessons in grades 4-8. "The pre-application of the DynEd English Language Education System was carried out in 11,152 primary schools in the 2007-2008 academic year, and it has been implemented in all official primary schools with internet connection throughout the country since the 20082009 academic year" (MEB, 2007, p.56). Thanks to such materials, it will be possible to teach subjects that have important problems in teaching and learning much more effectively and at higher learning levels. In line with the purpose of this research, topics are explained with a rich visual presentation and animations in the primary school 4th grade English lessons prepared by the researcher in accordance with the MEB curriculum; students are enabled to interact with the computer in various ways and to receive instant feedback.

\section{Method and Procedures}

\section{Research Design}

In this study, qualitative research design was used based on the method used concerning participant observations and in-depth interviews. Qualitative research was preferred to gather in-depth insights into the problem and generate new ideas for the study. It has been tried to reveal the differences in the motivation levels of students who receive online education in English language teaching. Accordingly, these students were interviewed and their written opinions were taken. Later, these answers were analyzed and evaluated.

The research question of the study was:

- What is the effect of online education on students' academic development in English education?

In the study an appropriate answer was attempted to be given to this question with the help of previous studies and the analysis of the interviews.

\section{Research Setting and Participants}

The study was conducted on 4th grade students studying at different schools affiliated to the Ministry of National Education in the 2020-2021 academic year. The study was carried out with a total of 10 students, including boys and girls whose English course success scores were examined. Documentation of a comprehensive review of published and unpublished studies from various data sources related to the research has been 
documented.

This study attempts to illustrate the use of technology-assisted education in English language learning in 4th grade. Interviews were made with the participants online and written responses were requested. The results of the interviews were analyzed descriptively and interpreted accordingly. The sample of the study was limited to 4th grade students learning English. Further studies may be conducted in the future to assess the academic performance of students at other levels.

\section{Data Collection Instruments and Data Analysis}

The literature on the subject of the research has been scanned, and the findings and the basis of the theoretical part of the research have been formed. Motivation scale, presentations for English course and online education and computer aided teaching software were used to collect data in the study. In order to answer the question of the study, an instructional software was used. The instruction software consisted of two main parts. The first part contains reading texts, explanation of the grammar items and presentation of the vocabulary items. The second part of the instructional software consists of exercises and drills on the reading passages and the grammar and vocabulary items. The instructional software was developed depending on the textbooks of 4th Grade English Book, Ministry of National Education (MEB) in 2019-2020 the educational period.

Preparing Computer Aided Instructional Materials Related to the Unit to be Treated: Before starting the application of the study, a computer-aided teaching software with unit content presentations was prepared for the 4th unit in the "Time for English Student's Book" English course book of the experimental group students. (The materials were collected in a CD.) These materials were first designed and prepared by the researcher himself by taking expert opinions, and then they were reconstructed by taking the opinions of the lesson teacher and 4 English lesson teachers. A number of corrections and additions were made to the relevant materials in line with the recommendations of curriculum development experts and teachers. Later, related software and presentations were made available to 6 students at the same level, while the students were using the materials, observations were made by the researcher.

Finally, the parts that students had difficulties in using were reviewed and the relevant materials were made ready for the application of BDI. Unit materials, which are finalized after the preparation process, have the following features:

- User instruction

- English grammar goals and behaviors covered by the research

- English grammar topics covered by the research

- Unit related games

- Songs related to the unit 
- Evaluation of the unit

The target behaviors for the unit were determined and the relevant materials were prepared by using the Primary School Curriculum English Program 4th grade textbook issued by the Ministry of National Education. (EK-CD).

The data were obtained from the literature review on the subject. We made use of various articles, books and theses on this subject in order to reveal our view on the existing information. Thus, it was tried to examine the advantages of using technology-based English reading lessons in Turkish context in terms of classroom activity, interest, teacher and classroom difficulty.

Previous studies evaluation of their results, she tried to talk about the influence of the 4th grade English level use of technology in Turkey. This study tries to examine the students' views on the effectiveness of online education in teaching English.

\section{Findings and Discussions}

After analysing the findings of the interviews and written answers from the participants, the following results have been achieved.

General information about the participants is given in Table 1. 
Table 1: General information of participants

\begin{tabular}{|c|c|c|c|c|c|}
\hline $\begin{array}{l}\text { Name of } \\
\text { the } \\
\text { Participant }\end{array}$ & Class & Age & $\begin{array}{l}\text { Online } \\
\text { Education } \\
\text { Programs }\end{array}$ & $\begin{array}{l}\text { Social } \\
\text { Media } \\
\text { Usage }\end{array}$ & $\begin{array}{l}\text { Computer } \\
\text { Skills }\end{array}$ \\
\hline Ayşe & $\begin{array}{l}\text { 4th } \\
\text { Grade }\end{array}$ & 11 & $\begin{array}{l}\text { Teams, zoom, } \\
\text { Google meet }\end{array}$ & $\begin{array}{l}\text { Youtube, } \\
\text { whatsapp, } \\
\text { telegram, } \\
\text { signal, } \\
\text { instagram, } \\
\text { facebook }\end{array}$ & $\begin{array}{l}\text { ptyhon, } \\
\text { Microsoft } \\
\text { Office, html }\end{array}$ \\
\hline Ahmet & $\begin{array}{l}\text { 4th } \\
\text { Grade }\end{array}$ & 10 & $\begin{array}{l}\text { Teams, zoom, } \\
\text { Google meet }\end{array}$ & $\begin{array}{l}\text { Youtube, } \\
\text { instagram, } \\
\text { facebook }\end{array}$ & Good \\
\hline Nuri & $\begin{array}{l}\text { 4th } \\
\text { Grade }\end{array}$ & 10 & $\begin{array}{l}\text { Teams, zoom, } \\
\text { Google meet }\end{array}$ & $\begin{array}{l}\text { instagram, } \\
\text { youtube, } \\
\text { whatsapp }\end{array}$ & $\begin{array}{l}\text { I can use it } \\
\text { moderately. }\end{array}$ \\
\hline Ebru & $\begin{array}{l}\text { 4th } \\
\text { Grade }\end{array}$ & 10 & zoom, eba & $\begin{array}{l}\text { youtube, } \\
\text { spotify }\end{array}$ & Good \\
\hline Sezer & $\begin{array}{l}\text { 4th } \\
\text { Grade }\end{array}$ & 11 & $\begin{array}{l}\text { Zoom, eba, } \\
\text { whatsapp }\end{array}$ & $\begin{array}{l}\text { whatsapp, } \\
\text { instagram, } \\
\text { signal, } \\
\text { facebook }\end{array}$ & Very Good \\
\hline Sami & $\begin{array}{l}\text { 4th } \\
\text { Grade }\end{array}$ & 11 & $\begin{array}{l}\text { EBA, Zoom, } \\
\text { Instagram }\end{array}$ & $\begin{array}{l}\text { Instagram, } \\
\text { Youtube }\end{array}$ & Good \\
\hline Faruk & $\begin{array}{l}\text { 4th } \\
\text { Grade }\end{array}$ & 10 & $\begin{array}{l}\text { eba, zoom, } \\
\text { Google meet. }\end{array}$ & $\begin{array}{l}\text { whatsapp, } \\
\text { signal, } \\
\text { instagram }\end{array}$ & Moderate \\
\hline Seda & $\begin{array}{l}\text { 4th } \\
\text { Grade }\end{array}$ & 10 & zoom, eba. & $\begin{array}{l}\text { whatsapp, } \\
\text { instagram }\end{array}$ & Moderate \\
\hline Aynur & $\begin{array}{l}\text { 4th } \\
\text { Grade }\end{array}$ & 10 & $\begin{array}{l}\text { zoom, cambly, } \\
\text { eba }\end{array}$ & $\begin{array}{l}\text { whatsapp, } \\
\text { facebook }\end{array}$ & Moderate \\
\hline Merve & $\begin{array}{l}\text { 4th } \\
\text { Grade }\end{array}$ & 10 & $\begin{array}{l}\text { zoom, cambly, } \\
\text { eba }\end{array}$ & $\begin{array}{l}\text { whatsapp, } \\
\text { facebook }\end{array}$ & Moderate \\
\hline
\end{tabular}

The opinions of the participants in the academic development of technology in online learning in English education are given in Table 2. It can be said that computer- 
assisted English instruction in the 4th grade of primary school has a positive effect on students' internal motivation. In addition, this finding supports the research findings that show that BDI activities positively affect students' achievements and attitudes. In the study of Kibar (2006), who reached the results supporting the findings of this research, it was found that BDI significantly increased student achievement and attitude compared to the traditional teaching method. According to the findings of the research, the achievement and attitude scores of the students who used the computer-assisted English teaching method in the 4th grade of primary school were higher than the control group students who were applied the traditional teaching method, and the difference between them was significant.

Table 2: Participant views on the importance of online learning and technology in academic development in English education

\begin{tabular}{cc}
\hline $\begin{array}{c}\text { Participant } \\
\text { Numbers }\end{array}$ & Answers \\
\hline 2 & It makes it easier to access information. \\
\hline 6 & Enjoyable, simple and easy \\
\hline 5 & It plays an important role in academic development. \\
\hline 4 & It provides easy access to information. \\
\hline 7 & It offers a lot of work opportunities. \\
\hline 4 & It saves time and is more convenient. \\
\hline 6 & Because I think my visual and auditory skills have \\
& increased. \\
\hline
\end{tabular}

Participants reported that they found online training fun and simpler. There are opinions that they save students time and contribute to their visual and auditory skills. Becaus the Internet can be accessed at any time, most students have the opportunity to reach every education regardless of time and place.

Ayşe and Sezer's opinions about the importance of technology in academic development in online learning in English education are given below;

"In my opinion, it makes learning English easier because it is faster and more useful."

"Since our school did not have a smart board, we could not do the listening texts, but because our teacher shared screens in online education, these deficiencies were eliminated thanks to technology, thus contributing positively to academic development."

Questions about the positive and negative aspects of online education were 
directed during the interview with the participants. The results of the interviews are given in Table 3.

Table 3: Participant opinions on online learning suggestions on academic development in English education

\begin{tabular}{cc}
\hline $\begin{array}{c}\text { Participant } \\
\text { Number }\end{array}$ & Answers \\
\hline 3 & More catchy activity can be created. \\
\hline 3 & They can make education play. \\
\hline 5 & English class hours may be increased. \\
\hline 6 & They can provide opportunities for students who do not have \\
access to online education.
\end{tabular}

Participants expressed opinions such as developing internet aly structures, increasing the course hours, contributing to English education by gamifying the contents in order to improve online education. Suggestions were made about online education, such as giving lectures to teachers and paying attention to students' views.

The suggestions for the development of online education in P4 and P6 English education are as follows;

"I think that the necessary arrangements should be made in the technological infrastructure related to online learning in our country, because I encounter many problems related to both internet-based and educational programs."

Not ignoring the motivation in foreign language learning supports the conclusion that students should be motivated by trying different strategies to benefit from different methods and tools such as computer-assisted English teaching, and the existing motivation should be maintained. It is obvious that English language teaching supported by technology is at a "good" level in terms of "intriguing, creating needs, difficulty level, positive results and effects, motivating formal features". The research, which is in parallel with the study, supports the findings. After the researches, it was concluded that the software prepared in the computer environment, containing interesting elements and highly interactive increased student motivation, and the results also support the research findings.

The study, which concluded that the participants who conducted English grammar exercises with web support, had higher English grammar success and attitudes towards the 
lesson compared to the control group students who were taught with the traditional teaching method, supports the research findings that it significantly increased student success. It also was also found that technology-supported education used in educational activities increases students' interest in the lesson, facilitates their learning and increases their motivation, and positively affects their attitudes towards the lesson and their metacognitive skills. Computers help students achieve their teaching goals, compared to traditional teaching, computer programs save $20 \%$ to $40 \%$ of learning time. After the computerassisted English teaching, students' scores of attitude towards computer and English increased significantly, which is parallel to their studies. In this way, it can be said that it increases student motivation significantly. In addition, it was observed that there was a significant difference in knowledge, comprehension and total achievement of the students after the application.

The research question of the study was: "What is the effect of online education on students' academic development in English education?" By means of motivation scale, it was discovered that students were very interested in computers and this interest should be assessed in the education environment in the teaching-learning process. With the help of online education and computer aided teaching software that were in this study, it was realized that computers should be used as a teaching tool in foreign language teaching.

The findings of this research justify the importance of adding technology into foreign language courses. Today students thrive on using computers at school, thus adding them into courses will help to engage students in their learning. In addition, using technology allows teachers to easily differentiate lessons and make sure that students are working on a lesson at their personal levels. Teachers should be sure to share new tools with one another so students are always actively engaged, as well as to make sure that there is an activity for students at every level.

As a result of the findings of the study, recommendations for researchers and practitioners are as follows:

1) Researchers can investigate the effectiveness of the computer-aided teaching method on the English course in other courses.

2) In the study, it was observed that students were very interested in computers and this interest should be evaluated in the education environment in the teachinglearning process and computers should be used as a teaching tool.

3) The study was carried out for primary school 4th grade students. Similar studies can be included in other educational levels and for different courses.

4) In the study, the student-centered dimension of computer-aided teaching practices has been investigated, and other variables (teacher training, software, hardware, etc.) of the method can also be studied by the researchers.

5) The English course program should be changed and developed in accordance with computer-assisted English education. 
6) In schools, computer laboratories should be established in accordance with the number of students who will apply the computer-aided teaching method and the quality of the course.

7) The software used in computer-aided education should be well prepared in terms of validity of scientific information, ease of use, suitability for the English program and students.

8) Trainings in which teachers will gain the necessary knowledge and skills to be able to perform computer-aided applications should be given by both undergraduate programs of education faculties that train teachers and in-service courses.

9) Cooperation should be made with the relevant departments of universities in computer aided education practices, and the researches on this subject should be followed by the teachers. Transmission of innovations on the subject to teachers and students can be achieved through in-service trainings.

10) Teachers who provide computer-aided education should be encouraged by the administrators and the necessary opportunities should be provided.

11) The effectiveness of the research has been seen in the short term. However, it is not known how its effect will change in the long term. For this reason, similar studies can be conducted for different units of the English course by investigating the long-term effect of the method.

12) Computer-aided teaching practices should be followed continuously, and if there are any missing or hitched aspects, they should be corrected on time. It should be ensured that there are experts in schools who can guide teachers in the problems they encounter in computer assisted education and in technical failures and errors.

\section{Conclusion}

This study has examined how technology influences foreign language learning and how it aids to students in reading while learning English. Data was obtained from literature review related to the subject. To present our view in relation to existing knowledge, various articles, books and thesis related to the subject were utilized. Within this context, we tried to examine the advantages of using technology-based English reading lessons in the Turkish context in terms of classroom effectiveness, interest, tutor and classroom difficulty.

With the opportunities offered by technology, research and development studies on computer games have gained momentum in recent years. However, computer games, which are the subject of academic conferences, meetings, studies and books, have been shown as appropriate applications aiming to learn. In Online Educa in Berlin, one of 
Europe's biggest conferences held in the field of e-learning in 2006, the problems in using computer games for learning purposes and learning games within the framework of these problems were examined with their pros and cons. In the field of language teaching, scientific innovations and technological inventions are needed more than other sciences in social sciences. The main reason for this is to produce sounds and images belonging to the speakers of the taught language, and then to use them in language classes and laboratories as a course material.

Classroom teaching carries many problems. In classroom instruction, warning situations are usually presented to all students at the same time. In parallel with the developments in the field of informatics, computer technology has started to be used in the field of education and in foreign language teaching under the name of "Computer Aided Education" (BDI) since the early 1960s. The first applications are carried out in major universities in the USA, which are considered the cradle of this teaching technique, within the scope of different projects starting from 1965. Although the Computer Assisted Instruction method makes the field breathe a little, some problems specific to Programmed Teaching arise and there is not much progress in solving them. In response to these problems, this method, presented as "new", is basically developed on the principles of Programmed Instruction. The only difference is that electronic computers have replaced mechanical Teaching Machines. Thus, applications such as Artificial Intelligence Based Computer Aided Teaching and LOGO software, which emerged as a result of the developments in cognitive sciences and computer engineering (especially in the field of artificial intelligence), come to the forefront in the early 70's. The proliferation of microinformatics, especially personal computers (PC, desktop) in the 80's, started a new trend in the field. Personal computers are first connected to the U-Matic device that plays the laser disc (video-disc) and is used to control this device. With this connection, the concept of "interactivity" emerges, which offers more individual learning opportunities compared to previous technologies. With the addition of the computer-wound sound card towards the end of the 1980s, the invention of the CD-Rom (1987), the development of my Windows 3.1 operating system and the spread of the Internet network all over the world, the so-called "multimedia" (multimedia); a new era is entered in which text, sound and image can be used together.

Making use of technology opportunities in language teaching; provides innovation to processes, ease of learners and a fun educational process, ease of achieving gains, economy in process and cost, and instant feedback; it makes boring and traditional lesson environments for individuals taking the lesson into a more enjoyable and more attractive learning environment that they can learn by experiencing. Although educational computer games, which combine educational learning environment and game concepts, are similar to the design process of other educational environments in terms of their structure, it is necessary to focus on different points in order to realize effective learning in the game 
environment; in this context, developed design models for educational computer games are needed. It has started a new era in which educational computer games, which continue to increase in importance in every field, will provide effective learning processes in language teaching and learning activities can be carried out at an individual pace anytime, anywhere with permanent learning. It is recommended to prepare educational computer software in language teaching by taking design models into consideration, and to conduct researches to examine its effectiveness.

It is recommended that the researcher should be aware of the importance of interdisciplinary work and shape his work accordingly, while designing educational software that can be used in language teaching, with the reusability of the developed software, in crowded classrooms, where everyone can apply the material at the same time in accordance with the individual learning speed. It is an undeniable requirement that all technologies used in language teaching from past to present bring innovations to the field. In the process of parallelism of technology to work, educational software and educational games were designed and digital training sets became popular.

\section{References}

Akgün, E., Yarar, M., \& Dinçer, Ç. (2011). The evaluation of classroom management strategies of preschool teachers in classroom activities. Pegem Eğitim ve Öğretim Dergisi, 1(3), 11.

Alkan, C. (1979). Açıköğretim: Uzaktan eğitim sistemlerinin karşılaştırmalı olarak incelenmesi. Ankara: Ankara Üniversitesi Eğitim Bilimleri Fakültesi Yayınları No: 157

Arslan, B. (2003). Bilgisayar destekli eğitime tabi tutulan ortaöğretim öğrencileriyle bu süreçte eğitici olarak rol alan öğretmenlerin bde'e ilișkin görüșleri. The Turkish Online Journal of Educational Technology - TOJET, 2(4), 35.

Bottino, R. M., Ferlino, L., Ott, M., \& Travella, M. (2006). Developing strategic and reasoning abilities with computer gamesat primary school level. Computers \& Education, 12, doi: 10.1016/ j. compedu.2006.02.003.

Christakis, D.A., Ebel, B.E., Rivara, F.P., \& Zimmerman, F.J. (2004). Television, video, and computer game usage in children under 11 years of age. The Journal of Pediatrics, 145, 112.

Cepni, S., Taş, E., \& Köse, S. (2006). The effects of computer-assisted material on students' cognitive levels, misconceptions, and attitudes towards science. Computers and Education, 46 (2), 66.

Doğan, H. (1997). Eğitimde program geliştirme ve ögretim tasarımı. Ankara: Önder Matbaacilik. 11.

Ertürk, S. (1972). Ëgitimde program geliştirme. Ankara: Yelkentepe Yayınları.12.

Kartal, E. (2005). Bilişim-iletişim teknolojileri ve dil öğretim endüstrisi [Informationcommunication technologies and language teaching industry]. The Turkish Online Journal of Educational Technology-TOJET, 4(4), 26.

MEB. (2007). Müfredat labortuar okulları modeli. Ankara: Eğitim Araştırma ve 
Geliştirme Dairesi Başkanlığ1, 56.

Rodinadze, S., \& Zarbazoia, K. (2012). The advantages of information technology in teaching English language. Frontiers of Language and Teaching, 3, 123-125

Solanki, D., \& Shyamlee1, M. P. (2012). Use of technology in English language teaching and learning: An analysis. International Conference on Language, Medias and Culture IPEDR vol. 33. IACSIT Press, Singapore. 12.

Taşpınar, H. K. (2004). Teachers' and students' perceptions of teachers' task-related motivational strategy use and students' motivation levels. Unpublished MA Thesis, Bilkent University Institute of Economics and Social Sciences. 25, Ankara.

Tezcan, M. (1988). Eğitim sosyolojisi. Eskişehir: Anadolu Üniversitesi Yayınları, No: 188. 12.

Y1ldırım, S. (1988). Current utilization of ICT in Turkish basic education schools: A Review fo Teacher's ICT Use and Barriers to Intecration. International Journal of Instructional Media, 34 (2), 46.

Warschauer, M., \& Meskill, C. (2000). Technology and second language learning. In J. Rosenthal (Ed.), Handbook of undergraduate second language education (pp. 303-318). Mahwah, New Jersey: Lawrence Erlbaum. 